\title{
Library School Programs and the Successful Training of Academic Librarians to Meet Promotion and Tenure Requirements in the Academy
}

\section{Rickey D. Best and Jason Kneip}

\begin{abstract}
This article relates an investigation of tenure and promotion practices for librarians at academic institutions. The study employed two surveys. The first survey determined the level of impact on promotion and tenure by recent publication in two top-tier peer-reviewed journals: College \& Research Libraries and Journal of Academic Librarianship. The second survey was developed and distributed to authors of articles in the two journals requesting information about the nature of their library positions. Although more research is warranted, it appears that librarians at academic institutions tend to publish more frequently in top-tier journals, enhancing our professional literature.
\end{abstract}

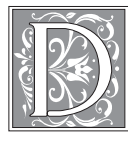

uring the winter of 2008, the Dean of the Auburn University at Montgomery Library was asked to investigate the tenure and promotion practices for librarians at other academic institutions. In developing the survey, we sought to discover any influence that publication in specific journals had for promotion and tenure, beyond the nature of a journal's being peer reviewed. We also sought to analyze the educational background of successful authors to determine whether or not there was a correlation between master's programs in library information science and the likelihood of success for graduates of those programs. A brief survey was developed and sent to directors and deans of libraries represented by authors who published in either College E Research Libraries or Journal of Academic Librarianship between 2000 and 2006. These two journals were selected because it was felt that these had the most direct correlation to academic libraries and that the importance of these titles would have some impact on tenure and promotion practices. Also, College \& Research Libraries and The Journal of Academic Librarianship are cited as "the major journals in academic librarianship." ${ }^{1}$

A second survey was developed and distributed to the authors of articles in the two journals requesting information including from what school they received their MLS degree. This survey was distributed to examine librarian productivity in research and publication and to attempt 
to ascertain the influence of the academic programs and training they received in their degree programs.

\section{Literature Review Tenure Status}

Our review of literature focused on two areas: Tenure and faculty status for librarians and publication patterns for librarians. Betsy Park and Robert Riggs reported on evaluative criteria used in promotion and tenure decisions for academic librarians. ${ }^{2}$ Park and Riggs determined by survey that job performance was the primary factor in achieving tenure and promotion, followed by service and scholarship. ${ }^{3}$ Park and Riggs also noted the distinction in expectations for research and publications among institutions. Liberal Arts schools, with smaller libraries and smaller library staff, rarely require librarians to publish. Larger research universities use research and publication as main components in the review process for tenure and promotion. ${ }^{4}$

Ronald Rayman and Frank Wm. Goudy submitted a questionnaire to ARL directors. The data from this survey indicated that, while "Faculty status and tenure eligibility were key elements in establishing publication as a requirement for librarians," only ten of the responding institutions required publication for promotion and tenure. One of the ten reported that it was required for promotion only. ${ }^{5}$ The Rayman and Goudy data showed that librarians were "encouraged" to publish but not required to do so at forty-one institutions. At seventeen institutions, librarians were not required to publish. ${ }^{6}$ Joyce Payne and Janet Wagner expanded upon the Rayman and Goudy study to include university libraries and four-year college libraries. Payne and Wagner surveyed fifty-nine academic libraries to determine not only the status of librarians but also information on terms of employment and educational requirements. ${ }^{7}$ Among their determinations was that 60 percent of the librarians in the survey held faculty status. To support librarians' efforts to conduct research and to publish, libraries and universities offered a variety of support services, including special leaves and sabbaticals; travel funds; and research funds for which the librarians compete with the teaching faculty. For the greatest number of librarians responding to the survey, publishing was an option for tenure and promotion. ${ }^{8}$ While encouraged, publishing was not cited by the librarians as an absolute requirement.

W. Bede Mitchell and L. Stanislava Swieszkowski provided research on publication requirements for librarians and the effect on tenure approval rates. ${ }^{9}$ Mitchell and Swieszkowski surveyed 147 U.S. academic libraries that were either full or associate members of the Center for Research Libraries. ${ }^{10}$ Mitchell and Swieszkowski reported that for a fiveyear period (1979-1983), 36.2 percent of the responding institutions held faculty status equivalent to that of the teaching faculty; 52.2 percent had an academic status separate or different from the teaching faculty, and 11.6 percent indicated that their particular institution had a nonacademic professional status for the librarians. ${ }^{11}$ Of the institutions surveyed (81), 58.7 percent (38) had tenure-track status for most or all of their librarians, and 41.3 (43) percent did not. Of the institutions with tenure-track status, 46.9 percent required evidence of research and publication before a librarian could achieve tenure, while 53.1 percent did not require publication. ${ }^{12}$

Of the institutions requiring research and publication, Mitchell and Swieszkowski found that 97.4 percent gave credit for publishing books, chapters in books, and refereed articles in the field of library/information science. The majority of institutions gave credit for publications outside the library field $(89.5 \%)$. The responding institutions did not have a requirement on the number of publications. ${ }^{13}$ The tenure approval rates for librarians in Mitchell and Swieszkowski's study was 81.5 percent. As noted by 
Mitchell and Swieszkowski, tenure-track status for librarians does not always imply the requirements to publish. ${ }^{14}$

Park and Riggs conducted a national survey of tenure and promotion policies for academic librarians in $1989 .{ }^{15}$ Park and Riggs observed that tenure evaluation for faculty is "anchored in effectiveness of teaching, scholarship, and service. For librarian faculty, evaluation is based on librarianship, scholarship, and service." 16 Park and Riggs noted the variance in the literature on the importance of publication in terms of tenure evaluation, stating that "Publication does not appear to play a pivotal role in the tenure in promotion process. It is one factor, but its importance is not clearly defined."17 In institutions where librarians held faculty status, Park and Riggs reported that 85 percent of the institutions evaluated the librarians on research and publications in addition to job performance. Where librarians held professional or other status, only 65 percent of the institutions evaluated research and publication in consideration of tenure and/or promotion. ${ }^{18}$ In analyzing their data, Park and Riggs noted that, while publication was evaluated by the majority of institutions in which librarians held faculty status, 70 percent of those institutions do not require publication, although publication may be encouraged. Sixteen percent of the faculty-status institutions do not review publication activity in tenure and promotion considerations. ${ }^{19}$

\section{Publication Patterns}

David F. Kohl and Charles H. Davis reported on ratings of journals by ARL Library Directors and Deans of Library and Information Science Schools in January of 1985 . Kohl and Davis investigated whether consensus existed in the perception of journal prestige by ARL Directors and Deans of Library and Information Science Schools and measured the perception of value for tenure and promotion. ${ }^{20} \mathrm{Kohl}$ and Davis determined journal rankings by establishing a single, weighted score for each journal by summing respondent rankings for a journal then dividing by the number of respondents. Respondents were asked not to rank a title they were not familiar with. A no response was calculated as a zero value. ${ }^{21}$ Kohl and Davis determined that, while there was rough agreement on the ratings for two-thirds of the journals, the deans and directors differed substantially in their rankings for the final one-third. The top five ranked journals for ARL directors were College $\mathcal{E}$ Research Libraries, Library Quarterly, Journal of Academic Librarianship, Library Resources and Technical Services, and Library Trends. For the deans of library schools, their top five ranked journals were Library Quarterly, Journal of the American Society for Information Science, College E Research Libraries, and Library Trends. The Journal of Academic Librarianship was ranked eleventh by the deans. ${ }^{22}$ Thomas Nisonger joined with Charles Davis to repeat the study that was published in 2005, increasing the number of journals to be ranked from thirty-one in the original study to seventy-one. ${ }^{23}$ Replicating the original Kohl and Davis survey, respondents were asked to rate journals on a 1 to 5 ordinal scale "concerning how important publication in that journal was for promotion and tenure at their institution." 24 Nisonger and Davis added a second component to the survey, asking the ARL Library Directors and the Deans of Library and Information Schools to list "in no particular order the five most prestigious journals to have published in for promotion and tenure purposes at your institution." ${ }^{25}$ Nisonger and Davis determined that there remained considerable stability in both the directors and the deans' perception of journals since the original study was conducted. ${ }^{26}$ The top five journals ranked by ARL directors in Nisonger and Davis's study include: $\mathrm{Col}$ lege $\mathcal{E}$ Research Libraries, Library Trends, Journal of Academic Librarianship, Library Quarterly, and Reference \& User Services Quarterly. For the deans, the top five titles were: Journal of the American Society for Information Science $\mathcal{E}$ Technology, Library 
Quarterly, Library \& Information Science Research, Annual Review of Information Science $\mathcal{E}$ Technology, and Information Processing $\mathcal{E}$ Management. In the deans' list, College $\mathcal{E}$ Research Libraries was ranked eighth, and the Journal of Academic Libraries was ranked twenty-third. ${ }^{27}$ The NisongerDavis study, like the earlier Kohl-Davis study, demonstrates that "a hierarchy of prestige among LIS journals does indeed exist, but the hierarchical order differs somewhat between the two constituencies. There is notable continuity in the perception of LIS journals over a twentyyear period, but more so in the directors' perceptions than in the deans'." 28

Mary Kim studied the rankings of library and information science journals by comparing perceptual measures (as used in the Kohl-Davis and Nisonger-Davis studies) with citation-based measures. ${ }^{29}$ Kim developed three hypotheses to test conceptions about journal prestige rankings. These were: Hypotheses set 1: LIS journals with higher prestige rankings will typically (a) be older journals, (b) have higher circulation rates, (c) be covered by more indexing services, and (d) be more research oriented. Hypotheses set 2: LIS journal prestige rankings will be significantly correlated with journal rankings by (a) total discipline citations, (b) discipline impact factor, (c) discipline immediacy index, $(\mathrm{d})$ references per paper, (e) Price's Index, (f) discipline citation factor, $(\mathrm{g})$ discipline popularity factor, $(\mathrm{h})$ discipline consumption factor, and (i) discipline self-citation rate. Hypothesis set 3 essentially restated Hypothesis set 2, with set 3 controlling for journal age, circulation, index coverage, and orientation. ${ }^{30}$

Kim's work indicated the following patterns existed: 1. Discipline citation measures identified a core of top journals that overlapped with the core listings of directors and deans for a similar time period; 2. library school deans and ARL directors valued publication in journals that "fed information to the network" and had an impact on current writing; deans specifically valued publication in journals with a research orientation, reflected by a higher number of references per paper and in older practitioner journals with higher consumption values; and 3. deans and directors appeared to use different criteria in judging the value of a publication for tenure and promotion. ${ }^{31}$

Pamela Bradigan and Carol Mularski surveyed 104 directors of libraries in the Carnegie Classifications of Research Universities I and II, and 104 directors in Doctorate-Granting Universities I and II to assess the values of academic librarians' publications for tenure and initial promotion. ${ }^{32}$ The survey created by Bradigan and Mularski examined library directors' ranked publication evaluation criteria for relative importance in the tenure and promotion process. The directors responded to criteria for ranking monographs and journal articles. For monographs, the following criteria were used: (a) solicited assessments of publications by experts outside the institution; (b) solicited assessments of publications by experts within the institution; (c) unsolicited assessments of publications (internal and external to institution); (d) reviews of the book/ monograph published in journals or other reviewing sources; (e) awards or other formal recognition of publications; (f) citations of publications; (g) OCLC search to check the number of institutions that own the item; and (h) quantity of publications. The criteria for journal articles included (a) the nature of the articles (that is, research paper vs. practice-based paper); (b) solicited assessments of articles by experts outside the institution; (c) solicited assessments of articles by experts within the institution; (d) unsolicited assessments of articles (internal and external to institution); (e) letters to the editor commenting upon the article; (f) awards/other formal recognition of articles; (g) citations of articles; (h) articles appearing in refereed journals; (i) indexing/abstracting services where the journal is listed; (j) perceived value of the journal to the profession; $(\mathrm{k})$ journal impact ranking from the Institute for Scientific Information's Citation Index- 
es; (l) requests for reprints; (m) quantity of journal articles. ${ }^{33}$

Within their survey responses, Bradigan and Mularski determined that 63.5 percent of libraries who responded that their librarians held faculty status required publication, as opposed to encouraging publication. ${ }^{34}$ Of the two types of institutions surveyed, research institutions were found to place a higher value on awards and other formal recognition of monographs and on assessment by experts outside the institution. For journal articles, research institutions placed a higher value on solicited assessments both from internal and external sources. Research institutions also rated article citations and awards for journal articles more highly than did doctoral-granting institutions. ${ }^{35}$ The respondents to the survey identified as the four most important criteria for monographs as being solicited assessments (both internal and external), awards, and reviews. Several directors, however, noted that the lack of a book publication would not prevent a candidate from attaining tenure and initial promotion. For journal articles, the four most important criteria were cited as being the article appearing in a refereed journal, the nature of the article, the perceived value of the journal to the profession, and solicited assessments of the articles by experts outside the institution. In comparing the survey results, Bradigan and Mularski noted the perfect agreement between library directors of research and doctoralgranting institutions on having articles appear in refereed journals. ${ }^{36}$ Bradigan and Mularski went on to recommend that librarians should "concentrate on writing research papers (e.g., reports of survey results, annotated bibliographies) rather than practice-based articles." ${ }^{\prime 37}$

Mickey Zemon and Alice Harrison Bahr conducted an analysis of articles written in College \& Research Libraries and Journal of Academic Librarianship and determined that college librarians author fewer articles than those in universities. ${ }^{38}$ Zemon and Bahr noted that, while previ- ous studies "affirmed the tenure requirement as the key impetus to publishing," it was not true for college librarians. In fact, noted Zemon and Bahr, more than 50 percent of the authors considered tenure the least important motivating factor. More than 70 percent of the college librarians published to share innovations or concerns and to achieve recognition. ${ }^{39}$ Zemon and Bahr also noted the regional characteristics of publication, with librarians from the Midwest and the Northeast publishing the most articles, while the West, Southeast, and Southwest published less. ${ }^{40}$

In an analysis of publication patterns of U.S. academic librarians from 1998 to 2002, Stephen E. Wiberley Jr., Julie M. Hurd, and Ann C. Weller noted a decline in the number of refereed articles published by academic librarians by 4.01 percent. ${ }^{41}$ Within College $\mathcal{E}$ Research Libraries and Journal of Academic Librarianship, Wiberley, Hurd, and Weller determined that academic librarians constituted 77 percent and 70 percent, respectively, of the authors published by the journals during the time period of 1998 to $2002 .{ }^{42}$ Wiberley, Hurd, and Weller also replicated the report from their 1993 to 1997 article on publication patterns by academic librarians to report on changes in rankings of the most "productive" libraries by measuring the number of authors from institutions and the number of articles published. ${ }^{43}$

\section{Summary}

The literature review demonstrates the importance of research and publication for librarians, either within the tenure process or within the promotion process. For those institutions at which librarians hold a professional status, publication is a significant determinant for gaining promotion. This remains true even where institutions do not "require" publication for promotion. In analyzing the publication patterns cited by Kim, Kohl-Davis, and Nisonger-Davis, the significant factor relative to journal prestige is whether or not the journal is peer reviewed. 


\section{The Directors Survey}

We began our survey with the Directors/Deans of libraries identified in articles published in College $\mathcal{E}$ Research Libraries or Journal of Academic Librarianship for the period 2000 to 2006. We limited our survey to fouryear colleges and universities, as these were the most like our institution. The survey was distributed by e-mail April 1, 2008, and respondents were asked to complete the survey by April 18. A total of 249 surveys were distributed in regional groupings, using the 1978 designations made by the ALA Committee on Accreditation of graduate library school programs as cited by Osgaard. ${ }^{44}$

The survey asked very basic questions: Do librarians at your institution hold faculty rank and tenure? Do you have written requirements for tenure and promotion? Do these requirements include publication in peer-reviewed journals? Is there a specific requirement in the number of peer-reviewed articles published for tenure? Do you have specific requirements in the number of peer-reviewed articles published for promotion? (These would be the number of articles published in addition to those published for tenure.) And, are specific journals given greater weight for tenure and/or promotion? The respondents were asked to list the titles.

We were particularly interested in the last question, as we wished to know if specific titles were being emphasized and whether we should direct our mentoring focus to aid our nontenured librarians to succeed in publishing in specific journals. Monographic publications were not emphasized in our survey because we are a smaller, regional institution, with limited support funds to assist librarians in the research efforts needed for monographic publications.

\section{Directors Survey Results}

The return rate for the directors' survey was 41.3 percent. Table 1 indicates the return rates by region.

\begin{tabular}{|c|c|c|c|}
\hline \multicolumn{4}{|c|}{$\begin{array}{c}\text { TABLE } 1 \\
\text { Library Directors' Survey Response } \\
\text { Rates by Region }\end{array}$} \\
\hline Region & $\begin{array}{c}\text { \# Surveys } \\
\text { Sent }\end{array}$ & $\begin{array}{l}\text { \# Surveys } \\
\text { Returned }\end{array}$ & $\begin{array}{c}\text { Return } \\
\text { Rate }\end{array}$ \\
\hline Midwest & 50 & 22 & $44.0 \%$ \\
\hline Northeast & 66 & 31 & $46.9 \%$ \\
\hline Southeast & 43 & 15 & $32.5 \%$ \\
\hline Southwest & 19 & 4 & $21.0 \%$ \\
\hline West & 37 & 17 & $45.9 \%$ \\
\hline Total & 215 & 89 & $41.3 \%$ \\
\hline
\end{tabular}

Our beginning analysis was to determine how many of the libraries operated with faculty rank and faculty status for their librarians. In examining the data, we realized that our initial survey was not detailed enough in that we did not include a category for "professional" status. Fortunately, the respondents were clear in providing this information. We also discovered, in looking at the data, that some institutions reported having faculty status for the librarians but did not have tenure-rather they maintained a continuing appointment similar to those institutions reporting a "professional" category for the librarians. In conducting our analysis, we examined the responses for faculty status by region. We also analyzed responses from ARL libraries to determine whether or not differences in faculty status could be observed. Table 2 contains the results of this analysis.

The other responses in this dataset included an institution that offered both a faculty status/tenure track and a professional track. The faculty-status track was identified as requiring more publications to achieve tenure. Two institutions reported that librarians held faculty status, but not tenure, indicating a lack of precision in the survey instrument.

With the non-ARL libraries responding to the survey, the overwhelming preference is for faculty rank and status. Only in the southwestern region was a professional status for librarians favored, and the sample results here are too small to 


\section{TABLE 2}

\section{Directors Survey on Faculty Status}

\begin{tabular}{|l|c|c|c|c|c|c|c|c|c|}
\hline \multirow{2}{*}{ Region } & \multicolumn{3}{|c|}{ Non-ARL } & \multicolumn{3}{c|}{ ARL } & \multicolumn{3}{c|}{ Total } \\
\cline { 2 - 11 } & $\begin{array}{c}\text { Faculty } \\
\text { Status }\end{array}$ & Professional & Other & $\begin{array}{c}\text { Faculty } \\
\text { Status }\end{array}$ & Professional & Other & $\begin{array}{c}\text { Faculty } \\
\text { Status }\end{array}$ & Professional & Other \\
\hline Midwest & 8 & 4 & 0 & 5 & 4 & 1 & 13 & 8 & 1 \\
\hline Northeast & 16 & 5 & 0 & 3 & 7 & 0 & 19 & 12 & 0 \\
\hline Southeast & 6 & 2 & 1 & 3 & 3 & 0 & 9 & 5 & 1 \\
\hline Southwest & 0 & 3 & 0 & 1 & 0 & 0 & 1 & 3 & 0 \\
\hline West & 13 & 1 & 0 & 2 & 0 & 1 & 15 & 1 & 1 \\
\hline Total & $\mathbf{4 3}$ & $\mathbf{1 5}$ & $\mathbf{1}$ & $\mathbf{1 4}$ & $\mathbf{1 4}$ & $\mathbf{2}$ & $\mathbf{5 7}$ & $\mathbf{3 0}$ & $\mathbf{3}$ \\
\hline
\end{tabular}

be conclusive. All together, 72.8 percent of the non-ARL libraries provided for faculty rank and status. Of the ARL libraries who responded, the results were almost evenly split: 46.6 percent provided faculty rank and status, 46.6 percent included librarians in a professional category, and 6.6 percent either offered a dual-status track where some librarians were on a faculty status with tenure and others were on a professional track, or where the librarians held rank and status, but not tenure.

The results of the survey are comparable to the data provided by Park and Riggs. ${ }^{45}$ Park and Riggs determined that 41.1 percent of 304 institutions surveyed provided librarians with faculty rank and status. ${ }^{46} \mathrm{As}$ a part of faculty rank and status, publication has been documented as a significant factor in assessment for tenure and promotion.

As noted by David Groves, tenure and promotion is a "feedback/communication process (Formative Evaluation). Whether it is tenure or promotion, a plan must be developed in teaching, research, and service." 47 A primary element of this communication process is the existence of written policies that communicate tenure and promotion policies and expectations. Within the AUM survey, library directors were asked to respond to the existence of written policies and procedures regarding tenure and promotion. Table 3 below provides the survey results.

\begin{tabular}{|c|c|c|c|c|c|c|}
\hline \multicolumn{7}{|c|}{$\begin{array}{r}\text { TABLE } 3 \\
\text { Written Policies for Tenur }\end{array}$} \\
\hline \multirow[t]{2}{*}{ Region } & \multicolumn{2}{|c|}{ Policies for $\mathrm{T} \& \mathrm{P}$} & \multicolumn{2}{|c|}{$\begin{array}{c}\text { Policies for Promotion } \\
\text { Only }\end{array}$} & \multicolumn{2}{|c|}{ No Written Policies } \\
\hline & ARL & Non-ARL & ARL & Non-ARL & ARL & Non-ARI \\
\hline Midwest & 5 & 9 & 4 & 1 & 0 & $3 *$ \\
\hline Northeast & 3 & 16 & 6 & 1 & $1 *$ & $4 *$ \\
\hline Southeast & 3 & 6 & 0 & 3 & $3 *$ & 0 \\
\hline Southeast & 1 & 0 & 0 & 2 & 0 & $1 *$ \\
\hline West & 2 & 13 & 1 & 0 & 0 & 1 \\
\hline $\begin{array}{l}\text { Regional } \\
\text { Total }\end{array}$ & 14 & 44 & 11 & 7 & 4 & 9 \\
\hline $\begin{array}{l}\text { Aggregate } \\
\text { Totals }\end{array}$ & \multicolumn{2}{|c|}{58} & \multicolumn{2}{|c|}{18} & \multicolumn{2}{|c|}{13} \\
\hline
\end{tabular}


Of the ARL libraries, 48.2 percent reported having written policies regarding tenure and promotion; 37.9 percent have written policies for promotion only. Surprisingly, 13.7 percent of the responding ARLs report having no written policies. For the non-ARLs, 73.3 percent have written policies regarding tenure and promotion; 11.7 percent have written policies for tenure only, while 15.0 percent report either the question was either not applicable because the institution does not provide for faculty status for the librarians or that they do not have written policies.

Mitchell and Swieszkowski, ${ }^{48}$ along with Floyd and Phillips, ${ }^{49}$ have reported on tenure as being "a key impetus" to publish, with nearly 80 percent of the authors surveyed by Floyd and Phillips reporting a requirement to publish. A major consideration, however, is the type of publication involved. Bradigan and Mularski have identified that 63.5 percent of the librarians holding faculty rank and status are required to publish articles in peer-reviewed publications. ${ }^{50}$ Table 4 below indicates the response rate by region for peer-reviewed publications.

The respondents to this question reported on whether peer-reviewed journal publications were required, encouraged, or not required. A number of institutions reported as Not Applicable the question because the institution did not provide faculty rank and status for the librarians. Of the ARL libraries, 82.6 percent either required or encouraged to publish. This is up significantly from the 76.0 percent identified in the Rayman and Goudy study. ${ }^{51}$ Only 17.2 percent listed no requirement for publication in regard to tenure and promotion. For the non-ARL libraries, 58.3 percent require publication, 30.0 percent encourage publication, and 11.7 percent do not require publication. Overall, 52.8 percent of the responding libraries require publication, 33.7 percent encourage publication, and 13.5 percent have no requirement. These figures overall are slightly lower than those cited by Bradigan and Mularski. ${ }^{52}$

Mitchell and Swieszkowski reported that 46.9 percent of the institutions with tenure-track status for their librarians required publication. ${ }^{53}$ Payne and Wagner observed that, for the majority of librarians in their study, publishing was an option rather than a requirement. ${ }^{54} \mathrm{In}$ examining the data in table 5 , we see that, of the 89 respondents in the survey, 48.3 percent of the institutions required peerreviewed articles. Another 23.6 percent of the institutions had peer-reviewed articles as one option in their tenure reviews, but the peer-reviewed injunction was not mandated. Finally, 28.1 percent of the

\begin{tabular}{|l|c|c|c|c|c|c|}
\hline \multicolumn{7}{|c|}{ PABLE 4 } \\
\hline \multirow{2}{*}{ Region } & \multicolumn{2}{|c|}{ Peer Review Required } & \multicolumn{2}{c|}{$\begin{array}{c}\text { Peer Review } \\
\text { Encouraged }\end{array}$} & \multicolumn{2}{c|}{ Not Required } \\
\cline { 2 - 8 } & ARL & Non-ARL & ARL & Non-ARL & ARL & Non-ARL \\
\hline Midwest & 4 & 5 & 5 & 6 & 0 & 2 N/A \\
\hline Northeast & 5 & 13 & 3 & 5 & 2 N/A & 3 N/A \\
\hline Southeast & 2 & 7 & 1 & 2 & 3 N/A & 0 \\
\hline Southeast & 0 & 1 & 1 & 1 & 0 & 1 N/A \\
\hline West & 1 & 9 & 2 & 4 & 0 & 1 N/A \\
\hline $\begin{array}{l}\text { Regional } \\
\text { Totals }\end{array}$ & $\mathbf{1 2}$ & $\mathbf{3 5}$ & $\mathbf{1 2}$ & $\mathbf{1 8}$ & $\mathbf{5}$ & $\mathbf{7}$ \\
\hline $\begin{array}{l}\text { Aggregate } \\
\text { Totals }\end{array}$ & & $\mathbf{4 7}$ & $\mathbf{3 0}$ & & $\mathbf{1 2}$ \\
\hline
\end{tabular}




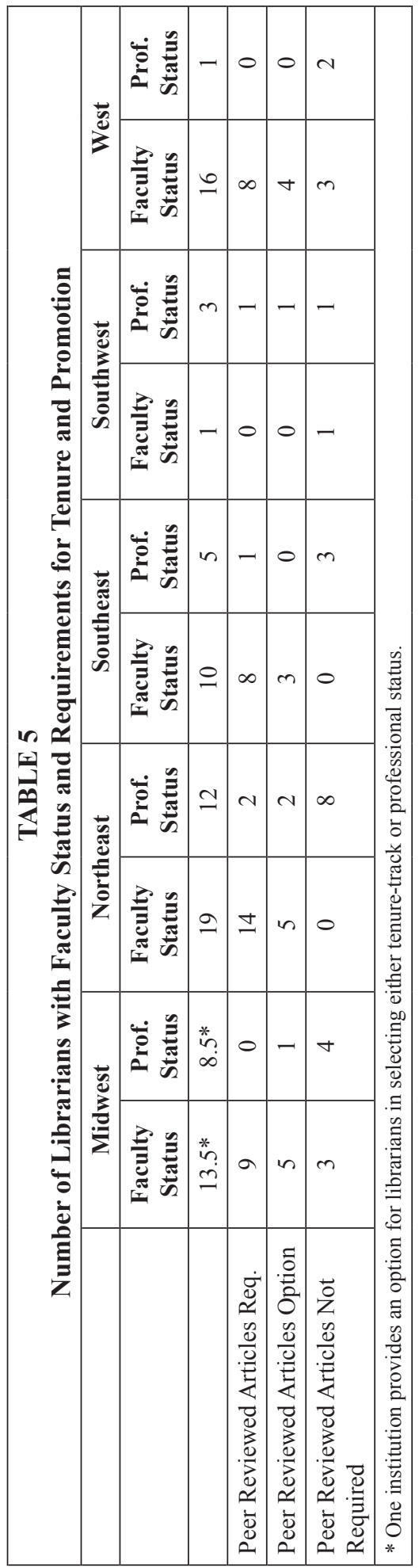

institutions did not require publication. Faculty status positions placed the greatest requirement on peer-reviewed publications. Institutions with faculty status for librarians equate to 90.6 percent $(n=29)$ of the requirement distribution, whereas institutions in which librarians hold a "professional" or other status comprised $9.3(n=2)$ percent of the requirement.

Our survey results indicated that librarians with faculty status have an option for peer-reviewed publications in 71.9 percent of the responding institutions, whereas 13.5 percent of the librarians with professional status have an option for consideration of peer-reviewed articles for promotion review consideration. Librarians with faculty status have no requirement for publication at 35.7 percent of the institutions, while professional status librarians have no requirement for publication at 64.3 percent of the institutions. While librarians with professional status do not have the same level of pressure for publication in peer-reviewed journals, the importance of publishing for successful career advancement can be seen in these results.

Librarians at ARL libraries who hold faculty status have requirements for peerreviewed publications at 84.6 percent of the institutions, versus 15.4 percent of the librarians in a professional classification. There is an even division between librarians with faculty status and professional status, with 50 percent of the institutions considering (but not requiring) peer-reviewed articles in submission for tenure and promotion decisions. Only 18.2 percent of faculty-status librarians in ARL institutions have no requirement to publish in peer-reviewed forums, while 81.8 percent of the professionalstatus librarians in those libraries have no publication requirements at all. These figures are significantly above those cited by Mitchell and Swieszkowski, ${ }^{55}$ Floyd and Phillips, ${ }^{56}$ or Bradigan and Mularski. ${ }^{57}$

Our final questions on the survey related to specific requirements for a number of peer-reviewed articles for tenure 
and for promotion. And, finally, we asked specifically if certain journals were given greater weight in tenure and/or promotion decisions. On question 4, dealing with the number of publications required for tenure, 43 institutions answered either " 0 " or "N/A." Twenty-eight institutions, 8 of which were ARLs, responded "Not specified. Four institutions (non-ARLs) required 1 to 2 publications for tenure; nine non-ARLs required 3 to 5 articles for tenure; and two ARLs required 3 to 5 articles for tenure. For question 5, asking for the number of peer-reviewed articles required for promotion, 37 institutions including 14 ARLs responded that there was no requirement or that the requirement was not applicable. No specifications were recorded by 35 institutions, including 9 ARLs. Five institutions, including 3 ARLs, require an additional 1 to 2 articles beyond tenure for promotion; 5 (including 1 ARL) require 3 to 5 articles for promotion; and 4 institutions, all non-ARLs, require 6 or more articles for promotion.

For the question on specific journals, 13 respondents listed that "peer-reviewed are given more weight," 8 directors listed a preference for "publications in librarianship," and one ARL director reported greater weight being given for "high impact journals." Five institutions, including one ARL, listed the following journals as being given greater weight in tenure and promotion decisions: College $\mathcal{E}$ Research Libraries (mentioned by 4 institutions); Journal of Academic Librarianship (mentioned by 3 institutions); Library Quarterly and Reference $\mathcal{E}$ User Services Quarterly, each mentioned once.

The data confirms that publication in peer-reviewed journals is a predominant job element for academic librarians, regardless of whether or not they are employed by an ARL library. Publication for tenure remains a significant element, but the data suggest that we are now seeing an increase in publication expectations for promotion as well. While faculty status remains the significant element in driving publication, those institutions with professional status use publication requirements in areas such as promotion.

\section{Librarians Survey Results}

Simultaneous to our survey of library directors, we conducted a survey of the authors of articles that were published in College \& Research Libraries or Journal of Academic Librarianship. In conducting our survey, we limited our coverage to academic librarians at four-year institutions who had published in these journals during the period from 2000 to 2006. A total of 428 surveys were distributed and 145 were returned, for a return rate of 33.87 percent. Table 6 shows the geographic breakdown for the respondents, based upon their current place of employment.

In the survey, we asked for the following information: name, institution/library in which they were employed, length of time employed as a librarian, the name of the school from which they received their master's degree in librarianship, whether or not their institution provided faculty rank and tenure for librarians, whether or not the respondent held tenure, and how many articles they had published in peer-reviewed library journals between 2000 and 2006. In asking for the number of articles, we listed options as $0,1,2,3$, and 4 or more.

\begin{tabular}{|l|c|c|c|}
\hline \multicolumn{5}{|c|}{ TABLE 6 } \\
\hline Librarian Survey Response Rates \\
\hline Region & $\begin{array}{c}\text { \# of Surveys } \\
\text { Sent }\end{array}$ & $\begin{array}{c}\text { \# of Surveys } \\
\text { Returned }\end{array}$ & $\begin{array}{c}\text { Return } \\
\text { Rate }\end{array}$ \\
\hline Midwest & 103 & 36 & $34.95 \%$ \\
\hline Sortheast & 126 & 36 & $28.57 \%$ \\
\hline Southeast & 87 & 28 & $32.18 \%$ \\
\hline West & 50 & 16 & $32.00 \%$ \\
\hline NA & 0 & 26 & $41.94 \%$ \\
\hline Total & $\mathbf{4 2 8}$ & 3 & $0 \%$ \\
\hline
\end{tabular}




\begin{tabular}{|c|c|c|c|c|c|c|c|c|c|c|c|}
\hline & & Numb & $\begin{array}{l}L \\
\text { er of }\end{array}$ & $\begin{array}{l}\text { braria } \\
\text { rticle }\end{array}$ & $\begin{array}{l}\text { CABL } \\
\text { n Sur } \\
\text { Pub }\end{array}$ & $\begin{array}{l}7 \\
\text { ey Re } \\
\text { shed f }\end{array}$ & ults & 00-20 & & & \\
\hline Region & & 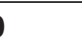 & & . & & 2 & & 3 & 4 or & nore & Total \\
\hline & ARL & $\begin{array}{l}\text { Non- } \\
\text { ARL }\end{array}$ & ARL & $\begin{array}{l}\text { Non- } \\
\text { ARL }\end{array}$ & ARL & $\begin{array}{l}\text { Non- } \\
\text { ARL }\end{array}$ & ARL & $\begin{array}{l}\text { Non- } \\
\text { ARL }\end{array}$ & ARL & $\begin{array}{l}\text { Non- } \\
\text { ARL }\end{array}$ & \\
\hline Midwest & 1 & 1 & 3 & 3 & 3 & 1 & 8 & 1 & 11 & 4 & 36 \\
\hline Northeast & 0 & 0 & 3 & 6 & 3 & 2 & 3 & 4 & 12 & 3 & 36 \\
\hline Southeast & 0 & 0 & 1 & 1 & 2 & 1 & 2 & 7 & 5 & 9 & 28 \\
\hline Southwest & 0 & 0 & 0 & 1 & 2 & 1 & 0 & 2 & 9 & 1 & 16 \\
\hline West & 0 & 0 & 1 & 4 & 1 & 3 & 0 & 3 & 8 & 6 & 26 \\
\hline Total & 1 & 1 & 8 & 15 & 11 & 8 & 13 & 17 & 45 & 23 & 142 \\
\hline
\end{tabular}

We asked for information such as name and institution to aid us in clarifying individuals who had similar names. The institution information was used to break down the survey results by ARL and non-ARL libraries, and thereafter by the geographic regions reported by Olsgaard. Our main function, however, was to measure the publication counts tied back to the school from which the individual received his or her MLIS degree. In table 7, we list the number of respondents, broken out by ARL and non-ARL categories, and the number of articles they cited.

In examining the data, we discovered that ARL librarians published at a greater rate than librarians in non-ARL libraries. The average number of articles published by the ARL respondents was 3.20, com-

\begin{tabular}{|c|c|c|c|}
\hline \multicolumn{4}{|c|}{$\begin{array}{c}\text { TABLE } 8 \\
\text { Librarian Survey Results } \\
\text { Number of Publications by ARL } \\
\text { and Non-ARL Librarians }\end{array}$} \\
\hline & ARL & $\begin{array}{l}\text { Non- } \\
\text { ARL }\end{array}$ & Total \\
\hline Midwest & 77 & 24 & 101 \\
\hline Northeast & 66 & 34 & 100 \\
\hline Southeast & 31 & 60 & 91 \\
\hline Southwest & 40 & 33 & 73 \\
\hline West & 35 & 43 & 78 \\
\hline Total & 249 & 194 & 443 \\
\hline
\end{tabular}

pared to the non-ARL average of 2.69. These data are consistent with the trends reported by Mitchell and Swieszkowski, ${ }^{58}$ Floyd and Phillips, ${ }^{59}$ and Bradigan and Mularski. ${ }^{60}$

Data from our survey indicate that the number of publications by ARL librarians is higher than that of librarians at non-ARL libraries. ARL librarians reported 249 publications compared to 194 by non-ARL librarians. In looking at the regions in which the respondents are currently employed, the Midwest is the most productive region overall with 101 publications, followed by the Northeast $(n=100)$, Southeast $(n=91)$, West $(n=78)$, and Southwest $(n=73)$. Because locations were not discernable for three individuals in the survey responses, these were not counted in the publication totals by region. Among ARL librarians, the Midwest was most productive with 77 articles published, followed by the Northeast $(n=66)$, the Southwest $(n=40)$, the West $(n=35)$, and the Southeast $(n=31)$. NonARL librarians were most productive in the Southeast, with 60 publications, followed by the West $(n=43)$, the Northeast $(n=34)$, the Southwest $(n=33)$, and the Midwest ( $\mathrm{n}=24)$.

We next examined the schools from which the respondents indicated receiving their MLIS. A total of 145 respondents indicated their schools. The top five schools listed were: the University of Il- 
linois Urbana-Champaign, the University of Wisconsin Madison, the University of Michigan, Indiana University, and tied for fifth were the University of Kentucky, the University of North Carolina Chapel Hill, the University of Pittsburgh, Kent State University, Syracuse University, and the University of Texas at Austin. The number of graduates for these schools is listed in table 9.
We then matched the schools from which the librarians graduated to the number of publications they reported and developed an average. In doing this, we observed that our survey question dealing with publications allowed respondents to select 4 or more publications. Because no specified number above 4 was required, we determined that the appropriate response was to

\begin{tabular}{|c|c|c|c|}
\hline \multicolumn{4}{|c|}{$\begin{array}{c}\text { TABLE } 9 \\
\text { Library School Programs Attended by Survey Respondents }\end{array}$} \\
\hline School & $\begin{array}{c}\text { \# of } \\
\text { Graduates }\end{array}$ & School & $\begin{array}{c}\text { \# of } \\
\text { Graduates }\end{array}$ \\
\hline $\begin{array}{l}\text { University of Illinois Urbana- } \\
\text { Champaign }\end{array}$ & 13 & $\begin{array}{l}\text { Clarion University of } \\
\text { Pennsylvania }\end{array}$ & 3 \\
\hline \multirow{2}{*}{$\begin{array}{l}\text { University of Wisconsin } \\
\text { Madison }\end{array}$} & \multirow[t]{2}{*}{7} & University of South Florida & 3 \\
\hline & & University of Iowa & 3 \\
\hline University of Michigan & 7 & \multirow{2}{*}{$\begin{array}{l}\text { Southern Connecticut State } \\
\text { University }\end{array}$} & \multirow[t]{2}{*}{2} \\
\hline Indiana University & 6 & & \\
\hline University of Kentucky & 5 & University of Arizona & 2 \\
\hline \multirow{2}{*}{$\begin{array}{l}\text { University of North Carolina } \\
\text { Chapel Hill }\end{array}$} & \multirow[t]{2}{*}{5} & Wayne State University & 2 \\
\hline & & University of South Carolina & 2 \\
\hline University of Pittsburgh & 5 & University of Denver & 2 \\
\hline Kent State University & 5 & University of Washington & 2 \\
\hline Syracuse University & 5 & Emporia State University & 2 \\
\hline University of Texas Austin & 5 & San Jose State University & 2 \\
\hline Louisiana State University & 4 & \multirow{2}{*}{$\begin{array}{l}\text { University of California Los } \\
\text { Angeles }\end{array}$} & \multirow[t]{2}{*}{2} \\
\hline University of Oklahoma & 4 & & \\
\hline SUNY Albany & 4 & University of Maryland & 2 \\
\hline Rutgers University & 4 & Simmons College & 2 \\
\hline Columbia University & 3 & University of Hawaii & 2 \\
\hline Emory University & 3 & University of Tennessee & 2 \\
\hline University of Chicago & 3 & University of North Texas & 2 \\
\hline University of Alabama & 3 & Florida State University & 1 \\
\hline Dominican University & 3 & \multirow{2}{*}{$\begin{array}{l}\text { University of Western } \\
\text { Ontario }\end{array}$} & \multirow[t]{2}{*}{1} \\
\hline SUNY Buffalo State & 3 & & \\
\hline University & & Dalhousie University & 1 \\
\hline Drexel University & 3 & McGill University & 1 \\
\hline \multirow{2}{*}{$\begin{array}{l}\text { University of Missouri- } \\
\text { Columbia }\end{array}$} & \multirow[t]{2}{*}{3} & Vanderbilt University & 1 \\
\hline & & Total & 145 \\
\hline
\end{tabular}


establish a base value of 4 , regardless of how many additional articles the respondent had published. To obtain an average number of articles per graduates at each institution, we divided the total number of articles published by authors from a specific program by the number of graduates for the school. This gave us a productivity average, which is reported in table 10.
As table 10 shows, three of the top six schools in terms of productivity for their graduates no longer offer ALA-accredited degrees. Columbia ceased its library school program in 1993. The programs at Emory University and the University of Chicago ceased in 1990. The top ten schools, in terms of productivity for publication, are Florida State University, Southern Connecticut State University,

\begin{tabular}{|c|c|c|c|}
\hline \multicolumn{4}{|c|}{$\begin{array}{c}\text { TABLE } 10 \\
\text { Average Number of Publications by MLIS School Attended }\end{array}$} \\
\hline & $\begin{array}{l}\text { Avg. Pubs } \\
\text { Per School } \\
(\mathrm{Max}=4)\end{array}$ & & $\begin{array}{l}\text { Avg. Pubs } \\
\text { Per School } \\
(\mathrm{Max}=4)\end{array}$ \\
\hline Columbia University & 4.00 & University of Washington & 3.00 \\
\hline Emory University & 4.00 & \multirow{2}{*}{$\begin{array}{l}\text { University of Western } \\
\text { Ontario }\end{array}$} & \multirow[t]{2}{*}{3.00} \\
\hline Florida State University & 4.00 & & \\
\hline \multirow{2}{*}{$\begin{array}{l}\text { Southern Connecticut State } \\
\text { University }\end{array}$} & \multirow[t]{2}{*}{4.00} & University of Michigan & 2.85 \\
\hline & & Indiana University & 2.83 \\
\hline University of Arizona & 4.00 & Kent State University & 2.80 \\
\hline University of Chicago & 4.00 & SUNY Albany & 2.75 \\
\hline Wayne State University & 4.00 & \multirow{2}{*}{$\begin{array}{l}\text { Clarion University of } \\
\text { Pennsylvania }\end{array}$} & \multirow[t]{2}{*}{2.66} \\
\hline University of Kentucky & 3.80 & & \\
\hline \multirow{2}{*}{$\begin{array}{l}\text { University of North } \\
\text { Carolina Chapel Hill }\end{array}$} & \multirow[t]{2}{*}{3.80} & Emporia State University & 2.50 \\
\hline & & Rutgers University & 2.50 \\
\hline University of Alabama & 3.66 & San Jose State University & 2.50 \\
\hline University of Pittsburgh & 3.60 & \multirow{2}{*}{$\begin{array}{l}\text { University of California Los } \\
\text { Angeles }\end{array}$} & \multirow[t]{2}{*}{2.50} \\
\hline University of South Carolina & 3.50 & & \\
\hline Dominican University & 3.33 & University of Maryland & 2.50 \\
\hline \multirow{2}{*}{$\begin{array}{l}\text { SUNY Buffalo State } \\
\text { University }\end{array}$} & \multirow[t]{2}{*}{3.33} & University of South Florida & 2.50 \\
\hline & & Syracuse University & 2.20 \\
\hline Louisiana State University & 3.25 & Dalhousie University & 2.00 \\
\hline University of Oklahoma & 3.25 & McGill University & 2.00 \\
\hline \multirow{2}{*}{$\begin{array}{l}\text { University of Wisconsin } \\
\text { Madison }\end{array}$} & \multirow[t]{2}{*}{3.14} & Simmons College & 2.00 \\
\hline & & University of Hawaii & 2.00 \\
\hline \multirow{2}{*}{$\begin{array}{l}\text { University of Illinois } \\
\text { Urbana-Champaign }\end{array}$} & \multirow[t]{2}{*}{3.07} & University of Tennessee & 2.00 \\
\hline & & Vanderbilt University & 2.00 \\
\hline Drexel University & 3.00 & University of Texas Austin & 1.80 \\
\hline University of Denver & 3.00 & University of Iowa & 1.66 \\
\hline $\begin{array}{l}\text { University of Missouri- } \\
\text { Columbia }\end{array}$ & 3.00 & University of North Texas & 1.50 \\
\hline
\end{tabular}




\begin{tabular}{|c|c|}
\hline \multicolumn{2}{|c|}{$\begin{array}{c}\text { TABLE } 11 \\
\text { ALA Accredited Programs by } \\
\text { Region }\end{array}$} \\
\hline Region & Number \\
\hline Midwest & 11 \\
\hline Northeast & 11 \\
\hline Southeast & 9 \\
\hline Southwest & 5 \\
\hline West & 5 \\
\hline Other (Foreign) & 3 \\
\hline Total & 44 \\
\hline
\end{tabular}

the University of Arizona, Wayne State University, University of Kentucky, University of North Carolina Chapel Hill, University of Alabama, University of Pittsburgh, the University of South Carolina, and Dominican University. Although College \& Research Libraries and The Journal of Academic Librarianship provided the baseline for identifying the authors, not all of their publications are within these journals.

Regionally, a total of 41 Library and Information Science programs from universities in the United States are listed in table 11. Breaking those schools down by region (see table 11), we see that 11 schools each are in the Midwest and Northeast regions of the country, followed by 9 in the Southeast, and 5 each in the Southwest and West.

In examining the curriculum of the top ten library schools, all contained a course on research methods. Additionally, special topics courses, field placements, and directed studies were listed indicating opportunities for training in the conducting of research. These courses and programs of study are consistent with both the 1992 and the 2008 versions of the American Library Association's Standards for Accreditation of Master's Programs in Library \& Information Studies. ${ }^{61}$ Both versions of the standards contain criteria I.2.5 under Mission, Goals, and Objectives. This standard stresses "the importance of research to the advance- ment of the field's knowledge base." Also included is standard II.3.2 under Curriculum, which states that the curriculum "emphasizes an evolving body of knowledge that reflects the findings of basic and applied research from relevant fields." ${ }^{62}$ Though further study on this point is required, it appears that the emphasis being placed on research training by the library schools is being reflected in the number of articles being produced by working librarians. To determine whether or not this is a valid interpretation, an examination of articles published in College \& Research Libraries and Journal of Academic Librarianship from 1993 to 2002 was conducted. In examining the publications, excluded were columns, bibliographies, editorials, and letters to the editors. Only unique articles with references were examined. A total article count was developed, and three types of authors were included: Library and Information Science faculty; working librarians in academic institutions; and "others." Only where an author was employed in a U.S. institution was it added into the total count. The "others" category included public and community college librarians, vendor representatives, and other university faculty. These data are included in table 12.

In their 2006 article, Wiberley, Hurd, and Weller examined thirty-two library journals and determined that there was a decrease of 3.75 percent in the number of refereed articles in library literature from 1993-1997 to 1998-2002. ${ }^{63}$ While Wiberley, Hurd, and Weller's study examined publication in thirty-two library journals, our study is limited to twoCollege $\mathcal{E}$ Research Libraries and Journal of Academic Librarianship. In comparing the publication rates of these two journals for the same time period, we discovered a 3 percent decrease in the number of articles for College $\mathcal{E}$ Research Libraries and an 8 percent increase in the number of articles published in Journal of Academic Librarianship for the period of 1998-2002. Overall, there was a 2 percent increase in 


\begin{tabular}{|c|c|c|c|c|c|c|c|}
\hline \multicolumn{8}{|c|}{$\begin{array}{c}\text { TABLE } 12 \\
\text { Author \& Article Comparisons in } C \& R L \text { and }\end{array}$} \\
\hline $\begin{array}{l}5 \text { Year } \\
\text { Period / } \\
\text { Journal }\end{array}$ & $\begin{array}{c}\# \\
\text { Articles }\end{array}$ & $\begin{array}{l}\text { \# LIS } \\
\text { Faculty }\end{array}$ & $\begin{array}{c}\% \\
\text { Articles } \\
\text { Authored }\end{array}$ & $\begin{array}{c}\# \\
\text { Librarians }\end{array}$ & $\begin{array}{l}\text { \% Articles } \\
\text { Authored* }\end{array}$ & $\begin{array}{c}\# \\
\text { Other }\end{array}$ & $\begin{array}{c}\% \\
\text { Articles } \\
\text { Authored }\end{array}$ \\
\hline \multicolumn{8}{|c|}{ 1993-1997 } \\
\hline$C \& R L$ & 183 & 34 & $19 \%$ & 220 & $65 \%$ & 29 & $16 \%$ \\
\hline$J A L$ & 157 & 18 & $11 \%$ & 183 & $75 \%$ & 22 & $14 \%$ \\
\hline Total & 340 & 52 & $15 \%$ & 403 & $70 \%$ & 51 & $15 \%$ \\
\hline \multicolumn{8}{|c|}{ 1998-2002 } \\
\hline$C \& R L$ & 179 & 30 & $17 \%$ & 237 & $64 \%$ & 34 & $19 \%$ \\
\hline$J A L$ & 169 & 19 & $11 \%$ & 166 & $59 \%$ & 50 & $30 \%$ \\
\hline Total & 348 & 49 & $14 \%$ & 403 & $62 \%$ & 84 & $24 \%$ \\
\hline $\begin{array}{l}\text { Grand } \\
\text { Total }\end{array}$ & 688 & 101 & $15 \%$ & 806 & $65 \%$ & 135 & $20 \%$ \\
\hline \multicolumn{8}{|c|}{$\begin{array}{l}\text { * In making the analysis, each article was calculated individually. Multiple authors were calculated } \\
\text { separately: for example, if a library school faculty member partnered with a member from another } \\
\text { department on campus and a working librarian in an academic library, each received credit for author- } \\
\text { ship. We did not exclude authors who published multiple articles in these journals. In examining the } \\
\text { articles within these two journals, multiple authors contributing to a work were only counted once. }\end{array}$} \\
\hline
\end{tabular}

the number of articles published in these two journals.

\section{Conclusion}

Considering the literature on tenure and faculty status for librarians, we believe that the necessity for publication is a strong influence for librarians in faculty and professional status-either for the achievement of tenure or for gaining promotion. This proposition agrees with the findings of Mitchell and Swieszkowski, ${ }^{64}$ Floyd and Phillips, ${ }^{65}$ as well as Park and Riggs, ${ }^{66}$ all of which identify the requirement for publication as a factor in tenure and promotion decisions. Zemon and Bahr, however, have documented that, for college librarians, writing for tenure was "the least important motivating factor," stating that "sharing innovations and concerns" and "recognition" were the most important factors encouraging these individuals to write. ${ }^{67}$ Whether it is a result of writing for tenure and promotion or in writing to share innovations and gain recognition, the influence of the research courses in library schools seems to be paying off. Of the top ten library schools, graduates reported published an average of 1.256 articles. The top school was Florida State, averaging 4 articles published, followed by Southern Connecticut State University, the University of Arizona, and Wayne State University, each averaging 2 articles published by graduates.

Additional research is needed before we can conclusively state that the library school programs are training individuals sufficiently skilled in research to be able to make it successfully through a tenure and promotion process. For additional research, it would be useful to survey academic librarians to determine where they received training in research and publication. However, it appears that the inclusion of research courses is benefiting the profession by enhancing its professional literature. 


\section{APPENDIX A: \\ Library Deans / Directors Survey}

1. Do Librarians at your institution hold faculty rank and tenure?

- Yes $\square$ No

2. Do you have written requirements for tenure and promotion?

$\square$ Yes $\square$ No

3. Do these requirements include publication in peer-reviewed journals?

$\square$ Yes $\square$ No

4. Is there a specific requirement in the number of peer-reviewed articles published for tenure?

$\square 0 \square 1-2 \quad \square 3-5 \quad \square 6$ or greater

5. Do you have specific requirements in the number of peer-reviewed articles published for promotion? These would be the number of articles published in addition to those published for tenure.

$\square 0 \square 1-2 \quad \square 3-5 \quad \square 6$ or greater

6. Are specific journals given greater weight for tenure and/or promotion? If so, please list the title(s) below:

\section{$C R L$ and $J A L$}

Authors Survey

Question 1: Please enter your name:

Question 2. Institution/Library Name:

Question 3: How long have you been employed as a librarian?

Question 4: From which professional school did you receive your Master's in Library/ Information Science?

Question 5: Do you work in an academic library where the librarians hold faculty rank and are eligible for tenure?

Question 6: Do you hold tenure?

Question 7: Since 2000, how many articles have you published in peer-reviewed library journals? (Please check)

$\square 0 \quad \square 1 \quad \square 2 \quad \square 3 \quad \square 4$ or more 


\section{Notes}

1. Mary K. Sellen, "Bibliometrics in Information Science: A Citation Analysis of Two Academic Library Journals," College \& Research Libraries 45, no. 2 (Mar. 1984): 129.

2. Betsy Park and Robert Riggs, "Tenure and Promotion: A Study of Practices by Institutional Type," Journal of Academic Librarianship 19, no. 2 (May 1993): 72-77.

3. Ibid., 76 .

4. Ibid.

5. Ronald Rayman and Frank Wm. Goudy, "Research and Publication Requirements in University Libraries," College \& Research Libraries 41, no. 1 (Jan. 1980): 44-45.

6. Ibid., 45 .

7. Joyce Payne and Janet Wagner, "Librarians, Publication, and Tenure," College \& Research Libraries 45, no. 2 (1984): 133-39.

8. Ibid., 138.

9. W. Bede Mitchell and L. Stanislava Swieszkowski, "Publication Requirements and Tenure Approval Rates: An Issue for Academic Librarians," College \& Research Libraries 46, no. 3 (May 1985): $249-55$.

10. Ibid., 250.

11. Ibid.

12. Ibid., 252.

13. Ibid., 253.

14. Ibid., 253-54.

15. Betsy Park and Robert Riggs, "Status of the Profession: A 1989 National Survey of Tenure and Promotion Policies for Academic Librarians," College \& Research Libraries 52, no. 3 (May 1991): 275-89.

16. Ibid., 277.

17. Ibid.

18. Ibid., 285 .

19. Ibid., 286.

20. David F. Kohl and Charles H. Davis, "Ratings of Journals by ARL Library Directors and Deans of Library and Information Science Schools," College \& Research Libraries 46, no. 1 (1985): $40-47$.

21. Ibid., $41-42$.

22. Ibid., 42.

23. Thomas E. Nisonger and Charles H. Davis, "The Perception of Library and Information Science Journals by LIS Education Deans and ARL Library Directors: A Replication of the KohlDavis Study," College \& Research Libraries 66, no. 4 (2005): 341-77.

24. Ibid., 343; David F. Kohl and Charles H. Davis, "Ratings of Journals by ARL Library Directors and Deans of Library and Information Science Schools," College E Research Libraries 46, no. 1 (1985): 45.

25. Nisonger and Davis, "The Perception of Library and Information Science Journals," 344.

26. Ibid., 361.

27. Ibid., 369-71.

28. Ibid., 374-75.

29. Mary T. Kim, "Ranking of Journals in Library and Information Science: A Comparison of Perceptual and Citation-Based Measures," College \& Research Libraries 52, no. 1 (1991): 24-35.

30. Ibid., 27.

31. Ibid., 34.

32. Pamela S. Bradigan and Carol A. Mularski, "Evaluation of Academic Librarians' Publications for Tenure and Initial Promotion," Journal of Academic Librarianship 22 (Sept. 2006): 360-65.

33. Ibid., 361.

34. Ibid.

35. Ibid., 361-62.

36. Ibid., 362-63.

37. Ibid., 364.

38. Mickey Zemon and Alice Harrison Bahr, "An Analysis of Articles by College Librarians," College E Research Libraries 59, no. 5 (1998): 422-32.

39. Zemon and Bahr, "An Analysis of Articles by College Librarians"; Mitchell and Swieszkowski, "Publication Requirements and Tenure Approval Rates."

40. Zemon and Bahr, "An Analysis of Articles by College Librarians."

41. Stephen E. Wiberley Jr., Julie M. Hurd, and Ann C. Weller, "Publication Patterns of U.S. Academic Librarians from 1998 to 2002," College \& Research Libraries 67, no. 3 (2006): 205-16. 
42. Ibid., 207 (Table 1).

43. Ann C. Weller, Julie M. Hurd, and Stephen E. Wiberley, Jr., "Publication Patterns of U.S. Academic Librarians from 1993 to 1997," College \& Research Libraries 60, no. 4 (1999): 352-61; Wiberley, Hurd, and Weller, "Publication Patterns of U.S. Academic Librarians from 1998 to 2002."

44. John N. Olsgaard and Jane Kinch Olsgaard, "Authorship in Five Library Periodicals," College \& Research Libraries 41, no. 1 (1980): 49-53.

45. Mitchell and Swieszkowski, "Publication Requirements and Tenure Approval Rates"; Park and Riggs, "Tenure and Promotion"; Park and Riggs, "Status of the Profession."

46. Park and Riggs, "Status of the Profession."

47. David L. Groves, "Criteria for Tenure and Promotion Decisions," Education 110 (2001): 164.

48. Mitchell and Swieszkowski, "Publication Requirements and Tenure Approval Rates."

49. Barbara L. Floyd and John C. Phillips, "A Question of Quality: How Authors and Editors Perceive Library Literature," College \& Research Libraries 58, no. 1 (1997): 85.

50. Bradigan and Mularski, "Evaluation of Academic Librarians' Publications for Tenure and Initial Promotion," 361. 44.

51. Rayman and Goudy, "Research and Publication Requirements in University Libraries,"

52. Bradigan and Mularski, "Evaluation of Academic Librarians' Publications for Tenure and Initial Promotion," 361.

53. Mitchell and Swieszkowski, "Publication Requirements and Tenure Approval Rates," 252.

54. Payne and Wagner, "Librarians, Publication, and Tenure," 138.

55. Mitchell and Swieszkowski, "Publication Requirements and Tenure Approval Rates," 253.

56. Floyd and Phillips, "A Question of Quality," 85.

57. Bradigan and Mularski, "Evaluation of Academic Librarians' Publications for Tenure and Initial Promotion," 361.

58. Mitchell and Swieszkowski, "Publication Requirements and Tenure Approval Rates," 253.

59. Floyd and Phillips, "A Question of Quality," 85.

60. Bradigan and Mularski, "Evaluation of Academic Librarians' Publications for Tenure and Initial Promotion," 361.

61. American Library Association, Standards for Accreditation of Master's Programs in Library \& Information Studies (1992), available online at www.ala.org/ala/educationcareers/education/ accreditedprograms/standards/Standards.rtf [Accessed 11 December 2008]; American Library Association, Standards for Accreditation of Master's Programs in Library \& Information Studies (2008), available online at www.ala.org/ala/educationcareers/education/accreditedprograms/ standards/standards_2008.pdf [Accessed 11 December 2008].

62. Ibid.

63. Wiberley, Hurd, and Weller, "Publication Patterns of U.S. Academic Librarians from 1998 to $2002, " 210$.

64. Mitchell and Swieszkowski, "Publication Requirements and Tenure Approval Rates," 249-55.

65. Floyd and Phillips, "A Question of Quality," 81-93.

66. Park and Riggs, "Status of the Profession."

67. Zemon and Bahr, "An Analysis of Articles by College Librarians," 430. 


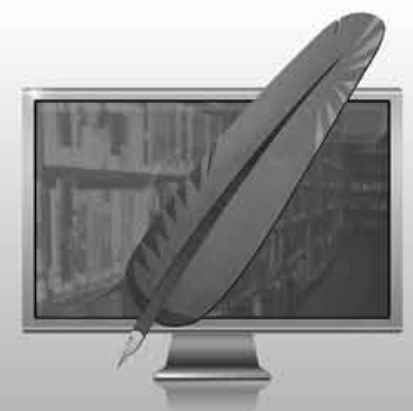

\section{SiteScripter Service Statistics}

The web-based solution for collecting and reporting patron transaction statistics simply and easily.

- No software to install or maintain

- Produce graphs of collected data

- Download collected data for use in spreadsheets

- Collect READ Scale values

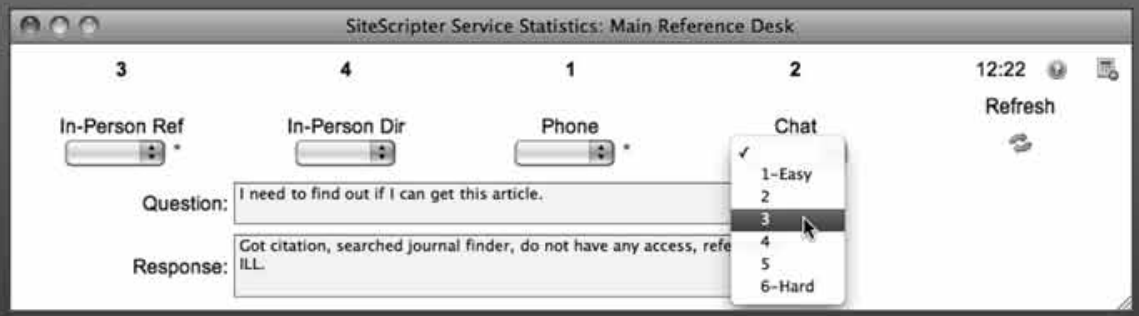

SiteScripter Service Statistics gives you the information you need to:

- Make management decisions on staffing levels

- Gauge the popularity of new services

- Produce standard reports

- Describe and compare service locations

Your first service location is FREE, so sign up today at: www.SiteScripter.com 